\title{
Sprawozdanie prezesa Polskiego Towarzystwa Teologicznego za rok 2019
}

\author{
ks. Kazimierz Panuś \\ Uniwersytet Papieski Jana Pawła II w Krakowie \\ kazimierz.panus@upjp2.edu.pl (D) https://orcid.org/0000-0002-9604-2920
}

Poprzednie walne zebranie Polskiego Towarzystwa Teologicznego odbyło się 26 lutego 2019 roku. Składało się z dwóch części. W pierwszej po wysłuchaniu sprawozdań prezesa, skarbnika, kierownika Sekcji Wydawniczej i przewodniczącego komisji rewizyjnej udzielono absolutorium zarządowi za rok 2018.

W drugiej części walnego zebrania po laudacji ks. dra hab. Bogdana Zbroi wręczono medal Zasłużony dla Polskiego Towarzystwa Teologicznego ks. prof. drowi hab. Tomaszowi Bolesławowi Jelonkowi oraz wysłuchano wykładu prof. dra hab. Romana Mazurkiewicza (Uniwersytet Pedagogiczny im. Komisji Edukacji Narodowej) nt. Deesis - idea wstawiennictwa Bogarodzicy i Jana Chrzciciela. Rok 2019 był trzecim rokiem działalności zarządu wybranego 28 lutego 2017 roku. Działał on w następującym składzie:

\section{Zarząd}

Prezes: ks. prof. dr hab. Kazimierz Panuś

Wiceprezes: ks. prof. dr hab. Piotr Kroczek

Sekretarz: o. dr hab. Romuald Kośla OFM

Skarbnik: ks. mgr Andrzej Fyda

Bibliotekarz: ks. dr hab. Jan Bednarczyk

Kierownik Sekcji Wydawniczej: mgr Sebastian Wojnowski

Komisja rewizyjna

Przewodniczący: ks. prof. dr hab. Tomasz Jelonek 
Członkowie: ks. dr hab. Sylwester Jędrzejewski SDB ks. dr hab. Witold Ostafiński

Sąd polubowny

Przewodniczący: ks. prof. dr hab. Maciej Ostrowski

Członkowie: o. prof. dr hab. Tomasz Dąbek OSB

ks. dr Franciszek Ślusarczyk

Z końcem 2019 roku Polskie Towarzystwo Teologiczne liczyło 970 członków, a w roku 2019 przyjęto 10 nowych. Od poprzedniego walnego zebrania do wiekuistego domu Ojca odeszli m.in. ks. mgr lic. Antoni Okrzesik, ks. dr Stanisław Krzywiński, o. dr Florentyn Piwosz OFM, o. mgr Mikołaj Rudyk OFM, o. dr Niward Karsznia OCist.

Spełniając wymogi statutowe, zarząd odbył w roku sprawozdawczym cztery zebrania w dniach 28 maja, 30 września i 26 listopada 2019 oraz 25 lutego 2020.

Pierwsze zebranie zarządu w roku sprawozdawczym 2019 odbyło się 28 maja w klasztorze Kanoników Regularnych Laterańskich w Krakowie przy ul. Bożego Ciała 26. Po przywitaniu członków zarządu przez ks. Piotra Adamusa CRL, rektora seminarium i zarazem przeora domu zakonnego, oraz proboszcza ks. Przemysława Sobonia CRL uczestnicy udali się do bazyliki na chwilę modlitwy przy grobie św. Stanisława Kazimierczyka. Następnie prof. Tomasz Węcławowicz, kierownik Sekcji Sztuki Sakralnej, przedstawił historię budowy kościoła i klasztoru, jednego z najcenniejszych zabytków kultury średniowiecznej w Krakowie i Europie środkowej. Członkowie zarządu mogli obejrzeć skarbiec muzealny z naczyniami i szatami liturgicznymi, a także starodruki i najstarsze dokumenty fundacyjne.

Podczas obrad zarządu prezes ks. Kazimierz Panuś pogratulował wiceprezesowi ks. prof. Piotrowi Kroczkowi wyboru do Rady Doskonałości Naukowej na I kadencję (2019-2023). Podziękował mu też za wszystkie wysiłki związane z nowelizacją statutu towarzystwa. Z kolei ks. prof. Kroczek dodał, że sprawa samej nowelizacji statutu jest zamknięta. Należy jeszcze opracować regulaminy dotyczące działalności towarzystwa (np. wyboru władz), ale to nie wymaga zatwierdzenia 
przez Konferencję Episkopatu Polski. Prezes zapoznał zebranych z treścią uchwały Konferencji Episkopatu Polski z dnia 12 marca w sprawie zatwierdzenia nowego statutu Polskiego Towarzystwa Teologicznego. Z sekretariatu Konferencji Episkopatu Polski przyszła także informacja o piśmie Andrzeja Rudlickiego, dyrektora Departamentu Wyznań Religijnych oraz Mniejszości Narodowych i Etnicznych w Ministerstwie Spraw Wewnętrznych i Administracji, potwierdzającym odbiór zawiadomienia o nowym statucie towarzystwa przez Ministra Spraw Wewnętrznych i Administracji. Statut zostanie przetłumaczony na język angielski w celu nawiązywania kontaktów z zagranicznymi towarzystwami teologicznymi.

Kolejnym punktem obrad była sprawa uwzględnienia Wydawnictwa UNUM Polskiego Towarzystwa Teologicznego w wykazie wydawnictw publikujących recenzowane monografie naukowe. Wydawnictwo UNUM prowadzone przez Sekcję Wydawniczą zostało ujęte w wykazie wydawnictw publikujących recenzowane monografie naukowe 17 grudnia 2019 roku (poziom I - 80 punktów, unikatowy identyfikator wydawnictwa: 75500). O wiele trudniejsza sytuacja jest natomiast z kwartalnikiem „Ruch Biblijny i Liturgiczny”, który nie został zgłoszony do konkursu Wsparcie dla czasopism naukowych, a tym samym nie zostanie poddany ewaluacji. Ks. dr hab. Stanisław Wronka, redaktor naczelny czasopisma, dodał, że kwartalnik nie spełnił kryterium udziału w konkursie z powodu przekroczenia w okresie 2 lat przed złożeniem wniosku 50-procentowego progu artykułów, których autorzy wskazali afiliację: Uniwersytet Papieski Jana Pawła II w Krakowie. Skutkiem tego kwartalnik nie otrzymał również dofinansowania na kolejny rok. W trakcie dyskusji padła propozycja, by szukać autorów wśród emerytowanych profesorów, którzy w przeszłości współpracowali z kwartalnikiem i dla których punkty nie stanowią już sprawy priorytetowej w dorobku naukowym.

W dalszej części spotkania podniesiono kwestię dobrego przygotowania obchodów stulecia towarzystwa. W tym celu powołano trzyosobową Radę Programową, w skład której weszli: s. prof. dr hab. Adelajda Sielepin CHR jako przewodnicząca, prof. Tomasz Węcławowicz i wiceprezes ks. prof. Piotr Kroczek jako członkowie. 
W dalszej części zebrania kierownicy sekcji i oddziałów zaprezentowali działalność naukową jednostek towarzystwa. Przy tej okazji ks. prof. Kazimierz Panuś poinformował, że na jego ręce wpłynęło podziękowanie od organizatorów XXI Ogólnopolskiego Zjazdu Studentów Archiwistyki za udzielony im patronat Polskiego Towarzystwa Teologicznego. Na zakończenie obrad przyjęto do towarzystwa 8 nowych członków. Zebranie zakończono - jak zwykle - modlitwą za zmarłych członków.

Drugie statutowe zebranie zarządu odbyło się 30 września w Krakowie przy ul. Kanoniczej 3. Prezes przywitał wszystkich zebranych, w szczególności kierowników oddziałów przybyłych z odległych miast: ze Szczecina - ks. inf. prof. Andrzeja Offmańskiego i z Włocławka ks. dra hab. Lecha Króla. Następnie wiceprezes ks. prof. Piotr Kroczek, kościelny inspektor ochrony danych, wystąpił z referatem nt. Ochrona danych osobowych $w$ Kościele. Wystąpienie to spotkało się z żywym zainteresowaniem zebranych, czego wyrazem była długa dyskusja. $\mathrm{W}$ kolejnym punkcie programu zapoznano się z wnioskami z posiedzenia Rady Programowej, powołanej na poprzednim zebraniu zarządu, której zadaniem jest opracowanie koncepcji obchodów stulecia towarzystwa. Przewodnicząca zespołu s. prof. Adelajda Sielepin CHR zaapelowała do członków zarządu o składanie propozycji tych obchodów. Kolejnym podjętym problemem była sytuacja kwartalnika „Ruch Biblijny i Liturgiczny, który nie znalazł się na liście czasopism punktowanych i nie otrzymał dofinansowania z Ministerstwa Nauki i Szkolnictwa Wyższego. Głos w tej sprawie zabierał redaktor naczelny ks. dr hab. Stanisław Wronka i ks. prof. Janusz Królikowski, który przedstawił ubolewanie środowisk teologicznych w Polsce z powodu dziwnej i nieczytelnej ewaluacji czasopism z dziedziny nauk teologicznych. Do grona członków przyjęto jedną osobę.

Trzecie przewidziane statutem zebranie zarządu odbyło się 26 listopada w gościnnych murach Domus Mater Księży Sercanów przy ul. Saskiej 2c w Krakowie. O godzinie 15.00 (w Godzinie Miłosierdzia) w kaplicy domu odmówiono koronkę do Bożego Miłosierdzia w intencji wszystkich członków Polskiego Towarzystwa Teologicznego i o dalszy rozwój tej instytucji. Następnie zebranych przywitał przełożony domu, 
a zarazem kierownik Sekcji Liturgicznej ks. dr Stanisław Mieszczak SCJ, przedstawiając historię tego miejsca i podejmowane aktualnie zadania. Właściwe posiedzenie zarządu rozpoczął wykład ks. prof. Romana Sieronia nt. „Pedagogia życia” sługi Bożego ks. prof. Wincentego Granata (1900-1979), rektora KUL antidotum na kryzysy i cierpienia ery post-nowoczesnej. W swoim przedłożeniu kierownik oddziału sandomierskiego przybliżył postać ks. Wincentego Granata, wybitnego dogmatyka i rektora Katolickiego Uniwersytetu Lubelskiego, zwanego Doctor Humanus i jego założenia pedagogiczne. Następnie zebrani podjęli temat przygotowań do obchodów stulecia Polskiego Towarzystwa Teologicznego. Postanowiono zwrócić się do ks. prof. Józefa Wołczańskiego o podjęcie badań archiwalnych nad lwowskimi początkami towarzystwa, a ks. drowi hab. Stanisławowi Wronce powierzono opracowanie historii czasopism naukowych wydawanych przez towarzystwo w okresie minionego stulecia. Ksiądz Prezes odczytał zebranym projekt pisma do dra Jarosława Gowina, ministra nauki i szkolnictwa wyższego, z prośbą o uwzględnienie kwartalnika „Ruch Biblijny i Liturgiczny” w wykazie czasopism naukowych i recenzowanych materiałów z konferencji międzynarodowych wraz z przypisaną liczbą punktów. W liście podkreślono, że periodyk ten jest recenzowanym czasopismem naukowym publikowanym od 1948 roku, ukazuje się dwujęzycznie po polsku i po angielsku online w otwartym dostępie w Open Journal Systems 3 dzięki finansowaniu Ministra Nauki i Szkolnictwa Wyższego ze środków na Działalność Upowszechniającą Naukę, a zgodnie z wykazem czasopism naukowych zawierającym historię czasopisma z publikowanych wykazów za lata 2013-2016 z 26 stycznia 2017 za publikację w „Ruchu Biblijnym i Liturgicznym” przyznawanych jest 11 punktów. W dalszej części zebrania omówiono organizację walnego zebrania, które zaplanowano na 25 lutego 2020 roku. W części uroczystej poświęcone ono będzie uczczeniu 100 rocznicy urodzin Karola Wojtyły, który był czynnym członkiem towarzystwa i publikował w nim swoje prace, m.in. Osobę i czyn. Przychylono się też do prośby o. dra hab. Romualda Kośli OFM o zwolnienie go z obowiązków sekretarza Polskiego Towarzystwa Teologicznego. Prośba ta zostanie przedstawiona na walnym zebraniu, które będzie także zebraniem wyborczym. W trakcie zebrania zarządu 
przedstawiono także działalność sekcji i oddziałów terenowych towarzystwa i zaprezentowano ich działalność. Do towarzystwa przyjęto jednego nowego członka.

Czwarte przewidziane przez statut zebraniu zarządu odbyło się 25 lutego 2020 roku. Zarząd zapoznał się i ostatecznie zaaprobował program obchodów stulecia Polskiego Towarzystwa Teologicznego. W ramach tych obchodów odbędzie się sympozjum przypominające powstanie i rozwój towarzystwa, wydawane przez nie publikacje. Odbędą się też debaty podejmujące aktualne tematy teologiczne, wydana zostanie księga jubileuszowa i sprawowana będzie uroczysta Eucharystia. Podjęto uchwałę w sprawie dofinansowania ze środków towarzystwa wydawania kwartalnika „Ruch Biblijny i Liturgiczny” w roku 2020. Przyjęto 4 nowych członków.

\section{Działalność sekcji specjalistycznych}

W ramach Polskiego Towarzystwa Teologicznego działa 15 sekcji specjalistycznych w Krakowie i 17 oddziałów terenowych, a także Sekcja Wydawnicza prowadząca Wydawnictwo UNUM.

Sekcja Biblijna. Kierownikiem sekcji jest ks. dr hab. Roman Bogacz, prof. UPJPII. W roku sprawozdawczym sekcja zorganizowała jedno posiedzenie w dniu 23 stycznia 2020 roku w budynku Sióstr Urszulanek Unii Rzymskiej przy ul. Starowiślnej 9. W jego trakcie prelekcję pt. O niechcianym Psalmie 83 wygłosił ks. dr Wojciech Węgrzyniak. Prelegent wręczył uczestnikom spotkania swoją książkę pt. Psalm 83. Teksty - egzegeza - konteksty, a następnie przedstawił tekst omawianego psalmu w tekstach hebrajskich, w edycjach drukowanych, w wersjach antycznych, w tekstach zrekonstruowanych oraz w tłumaczeniach współczesnych. Następnie przedstawił wybrane zagadnienie dotyczące słownictwa, struktury i figur retorycznych. Kolejno zaprezentował analizę semantyczną wybranego wersetu. Więcej uwagi poświęcił badaniom dotyczącym kontekstu historycznego, literackiego i interpretacyjnego (tradycja judaistyczna, tradycja chrześcijańska) oraz kontekstu liturgicznego. 
Ponadto Sekcja Biblijna współorganizowała wraz z Instytutem Nauk Biblijnych Uniwersytetu Papieskiego Jana Pawła II w Krakowie oraz Katedrą Kulturowych i Chrześcijańskich Podstaw Edukacji Akademii Ignacjanum w Krakowie, a także z Dziełem Biblijnym im. Jana Pawła II Archidiecezji Krakowskiej międzynarodową konferencję naukową na temat Biblia i społeczeństwo. Jan Paweł II -40-lecie pierwszej pielgrzymki do Ojczyzny. Konferencja odbyła się na Uniwersytecie Papieskim Jana Pawła II w Krakowie 18 czerwca 2019 roku. Wystąpiło na niej 22 prelegentów z Polski, Słowacji, Ukrainy i Czech. Członkowie Sekcji Biblijnej brali udział w comiesięcznych seminariach naukowych organizowanych przez Polskie Centrum Syndonologiczne. Ważnym wydarzeniem, w którym uczestniczyła Sekcja Biblijna, był III Dzień Całunu, zorganizowany 19 października w Miechowie. Oprócz modlitwy odbyła się też prezentacja kopii całunu dla przybyłych gości oraz konferencja naukowa, podczas której zaprezentowano historię całunu, a także najnowsze badania prowadzone nad tą szczególną relikwią męki Pańskiej. 21 listopada Sekcja Biblijna uczestniczyła także w Międzynarodowym Sympozjum Biblijnym pt. Duch Mówi - Kościół słucha.

Sekcja Teologii Moralnej. Sekcję prowadzi ks. dr Bogusław Mielec. W roku sprawozdawczym sekcja odbyła dwa spotkania poświęcone nauczaniu moralnemu papieża Franciszka w oparciu o najnowsze dokumenty. Zakończono tym samym cykl spotkań, których owocem będzie kolejna książka o. prof. Jarosława Kupczaka OP pt. Amoris laetitia. Konflikt interpretacji, która ukaże się latem 2020 roku w Wydawnictwie W drodze. Sekcja przygotowała merytorycznie dwie konferencje naukowe. Pierwsza, poświęcona 40 rocznicy początku pontyfikatu św. Jana Pawła II miała miejsce w październiku 2018 roku, a jej dokumentacja ukazała się w 2019 roku w książce pt. Jan Paweł II, który zmienił oblicze świata, red. R. Tyrała, B. Mielec (Uniwersytet Papieski Jana Pawła II w Krakowie Wydawnictwo Naukowe). Druga konferencja odbyła się 17 czerwca 2019 roku i była poświęcona 40 rocznicy pierwszej pielgrzymki Jana Pawła II do Wadowic. Publikacja dokumentująca to wydarzenia ukaże się w październiku 2020. 
Sekcja Homiletyczna. Kierownikiem sekcji jest ks. prof. dr hab. Kazimierz Panuś. W roku sprawozdawczym kierownik sekcji wygłosił wykład nt. Tajemnica słowa i sztuka jego przekazu podczas XXVI Ogólnopolskiej Konferencji Naukowej nt. Postęp naukowo-techniczny i organizacyjny w rolnictwie zorganizowanej przez Polskie Towarzystwo Inżynierii Rolniczej, Komitet Techniki Rolniczej PAN oraz Instytut Inżynierii Rolniczej i Informatyki Uniwersytetu Rolniczego w Krakowie. W grudniu 2019 ukończono prace nad projektem pt. Kazania $w$ kulturze polskiej. Edycje kolekcji tematycznych: kazania adwentowe, bożonarodzeniowe, wielkanocne i patriotyczne zgłoszonym przez Polskie Towarzystwo Teologiczne i finansowanym w ramach Narodowego Programu Rozwoju Humanistyki w latach 2015-2019.

Sekcja Duchowości. Kierownikiem sekcji jest ks. dr Wojciech Mleczko CR. W roku sprawozdawczym kontynuowano prace związane z wieloletnim programem badań naukowych nt. Duchowość klasztorów polskich: przekaz i komunikacja. Pragnąc udostępnić jak najszerszemu gremium odbiorców wyniki tych poszukiwań, przygotowano i wydano pracę zbiorową Ks. Paweł Smolikowski CR: życie dla Boga, Kościoła i społeczeństwa (red. W. Mleczko, Kraków 2019), będącą pokłosiem zeszłorocznego sympozjum na ten temat. Warto nadmienić, że w 2019 roku Stowarzyszenie Wydawnictw Katolickich FENIKS przyznało wyróżnienie w kategorii seria wydawnicza, dzieła zebrane serii Duchowość klasztorów polskich. Przekaz i komunikacja, pod redakcją ks. prof. dra hab. Wojciecha Misztala, wydawaną przez Wydawnictwo Naukowe Uniwersytetu Papieskiego Jana Pawła II w Krakowie. 13 marca w krakowskim Centrum Resurrectionis wraz z Katedrą Duchowości Mediów i Relacji Społecznych Instytutu Dziennikarstwa i Komunikacji Społecznej Wydziału Nauk Społecznych Uniwersytetu Papieskiego Jana Pawła II w Krakowie oraz Zgromadzeniem Zmartwychwstania Pańskiego sekcja zorganizowała siedemnaste już sympozjum z tej serii nt. Zmartwychwstańcy i odrodzenie Ojczyzny: $w 100$ rocznicę odzyskania niepodległości przez Polskę. Referaty wygłosiło 9 prelegentów z 7 różnych jednostek naukowych. W sympozjum wzięło udział około 100 słuchaczy. 
Ponadto po raz drugi Sekcja Duchowości we współpracy z Uniwersytetem Papieskim Jana Pawła II w Krakowie oraz Zgromadzeniem Zmartwychwstańców (Międzynarodowa Komisja Studiów Zmartwychwstańczych, Archiwum Generalne Zmartwychwstańców w Rzymie), zorganizowała Seminarium Zmartwychwstańcze. Miało ono miejsce w Domu Generalnym Zmartwychwstańców w Rzymie w dniach 1-2 czerwca 2019 roku. Uczestniczyło w nim 7 prelegentów z 7 jednostek naukowych.

W realizacji tych zadań biorą udział przedstawiciele kilku środowisk naukowych, takich jak Wydział Historii i Dziedzictwa Kulturowego, Wydział Nauk Społecznych, Wydział Teologiczny, Wydział Teologiczny Sekcja w Tarnowie Uniwersytetu Papieskiego Jana Pawła II w Krakowie, Instytut Teologii Duchowości Papieskiego Wydziału Teologicznego we Wrocławiu, Wydział Teologiczny Uniwersytetu Kardynała Stefana Wyszyńskiego, Centrum Duchowości Zmartwychwstańczej w Rzymie, Wyższe Seminarium Duchowne we Lwowie, Uniwersytet Jagielloński w Krakowie, Katolicki Uniwersytet Lubelski Jana Pawła II, Międzynarodowa Komisja Studiów Zmartwychwstańczych, Zgromadzenie Sióstr Zmartwychwstanek, Prowincja Polska Zgromadzenia Zmartwychwstańców, Komisja Historyczna Polskiej Akademii Nauk w Katowicach. Powzięte prace m.in. przyczyniają się do wymiany myśli, integracji środowiska naukowego oraz promowania dalszych badań nad duchową spuścizną polskich zakonów i jej oddziaływaniem.

Warto odnotować, iż kierownik sekcji od września 2016 roku jest konsultorem Komisji Duchowieństwa i członkiem zespołu ds. przygotowania nowych zasad formacji kapłańskiej w Polsce Konferencji Episkopatu Polski oraz członkiem dwóch międzynarodowych komisji Zgromadzenia Zmartwychwstańców: formacji i studiów zmartwychwstańczych.

Sekcja Pedagogiczno-Społeczna. Kierownikiem sekcji jest ks. dr hab. Grzegorz Godawa. W roku sprawozdawczym sekcja współorganizowała wraz z Katedrą Pedagogiki Ogólnej Wydziału Nauk Społecznych Uniwersytetu Papieskiego Jana Pawła II w Krakowie ogólnopolską konferencję naukową nt. Ojcostwo i jego odsłony, która odbyła się 23 maja w budynku przy ul. Bernardyńskiej 3. Konferencja 
zgromadziła specjalistów z zakresu poruszanej tematyki, a także liczne grono studentów oraz osoby spoza uniwersytetu. W ten sposób kontynuowano projekt przybliżania ważnych zagadnień społeczno-pedagogicznych środowisku akademickiemu.

Sekcja Dogmatyczna. Kierownikiem sekcji jest ks. dr hab. Jan Żelazny, prof. UPJPII. W roku sprawozdawczym sekcja prowadziła regularne comiesięczne spotkania członków poświęcone badaniom nad antykiem chrześcijańskim. Oprócz stałych uczestników brali w nich udział przedstawiciele środowisk naukowych Katowic i Tarnowa. Trwają prace związane z zorganizowaniem sympozjum sekcji nt. Wspólna tradycja chrześcijan. Będzie ono poświęcone działalności francuskiej organizacji L'Oeuvre d'Orient. Stowarzyszenie to założone 160 lat temu we Francji przez profesorów Sorbony wspomaga materialne chrześcijan z terenów Bliskiego Wschodu i stara się ocalić ich spuściznę teologiczną i kulturalną.

Sekcja Misjologiczna. Kieruje nią ks. dr. hab. Franciszek Jabłoński. W roku sprawozdawczym przeprowadził on wykłady z misjologii w Centrum Formacji Misyjnej dla przyszłych misjonarzy: w Kaliszu, Gnieźnie i we Wronkach oraz dla nowicjatu i postulatu sióstr pallotynek w Gnieźnie. Ks. Jabłoński zorganizował także XXI Szkołę Animatora Misyjnego w Białogórze dla 40 animatorów misyjnych. Kierownik sekcji przeprowadził także animację misyjną w 15 szkołach archidiecezji gnieźnieńskiej wraz z dr Michelem Robinsonem, lekarzem z Jamajki, ukazując rolę katolików w tym kraju. Ks. Jabłoński przeprowadził badania terenowe Kościoła w Chorwacji (Rijeka, 23-26 maja), w Austrii w diecezji Graz (6-10 czerwca), w archidiecezji lwowskiej (14-16 czerwca), w Libanie (23-28 września) i w Norwegii w Oslo (22-26 listopada). Kierownik sekcji wygłosił konferencję dla małżeństw w ramach Kongresu Małżeństw Diecezji Legnickiej (18 maja), wykład na Katolickim Uniwersytecie Lubelskim Jana Pawła II nt. Ochrzczeni i posłani, w ramach diecezjalnego kongresu misyjnego (5 września) oraz wykład inauguracyjny w seminarium duchownym w Kaliszu nt. Wyświęceni i posłani (22 października). Ks. Jabłoński wziął także udział w Międzynarodowym Sympozjum 
Misjologicznym na Uniwersytecie Kardynała Stefana Wyszyńskiego, prowadząc jedną z sesji (11-12 X) oraz w posiedzeniu Komisji ds. Misji Konferencji Episkopatu Polski w Częstochowie (18 XI). Zorganizowane zostało także XXVII spotkanie dla rodziców i krewnych misjonarzy pochodzących z archidiecezji gnieźnieńskiej.

Sekcja Prawa Kanonicznego. Kieruje nią o. dr Andrzej Kukła CSsR. W roku sprawozdawczym członkowie sekcji podejmowali ważne zadania dotyczące bieżących problemów prawnych w życiu Kościoła. Kierownik sekcji o. dr Andrzej Kukła prowadzi wykłady z prawa zakonnego na Università della Svizzera Italiana w Lugano (Szwajcaria) i dzięki temu nawiązał owocną współpracę z gronem profesorskim, studentami Wydziału Prawa na tymże uniwersytecie i z prof. Libero Gerosą, dziekanem Wydziału Teologii.

W roku sprawozdawczym Sekcja Prawa Kanonicznego organizowała, bądź współorganizowała spotkania i konferencje dotyczące problemów prawnych w życiu Kościoła i państwa polskiego. Członkowie sekcji prawa kanonicznego, którzy są często wykładowcami prawa kanonicznego w różnych seminariach duchownych i prowadzą wykłady w różnym zakresie prawa cywilnego i kościelnego, m.in. na Katolickim Uniwersytecie Lubelskim Jana Pawła II, Uniwersytecie Kardynała Stefana Wyszyńskiego i Uniwersytecie Papieskim Jana Pawła II w Krakowie, brali udział bądź byli bezpośrednio zaangażowani w organizację następujących konferencji: Obowiązki i prawa instytutów zakonnych oraz ich członków $w$ świetle kodeksu prawa kanonicznego (Wydział Prawa Kanonicznego Uniwersytetu Kardynała Stefana Wyszyńskiego, 27 kwietnia), VIII Ogólnopolska Konferencja Naukowa Kodeks prawa kanonicznego w badaniach młodych naukowców (Katolicki Uniwersytet Lubelski Jana Pawła II, 1 czerwca), Obowiązki i prawa instytutów zakonnych oraz ich członków w świetle kodeksu prawa kanonicznego (Wydział Prawa Kanonicznego Uniwersytetu Kardynała Stefana Wyszyńskiego, 27 kwietnia), konferencja naukowa z okazji jubileuszu 65-lecia Wydziału Prawa Kanonicznego Uniwersytetu Kardynała Stefana Wyszyńskiego (Warszawa, 15 czerwca), Dobra doczesne w stużbie charyzmatu i misji osób konsekrowanych (Economia a servizio del carisma e della missione) 
zorganizowana przez Wydział Prawa Kanonicznego Uniwersytetu Kardynała Stefana Wyszyńskiego (Warszawa, 23 października), Co mówić i jak mówić? Ochrona tajemnicy, dobrego imienia oraz intymności $w$ prawie Kościoła (Wydział Prawa Kanonicznego Uniwersytetu Papieskiego Jana Pawła II w Krakowie, 21 listopada). Członkowie sekcji współpracują też z Komisją Prawną Konferencji Episkopatu Polski.

Sekcja Liturgiczna. Pracami sekcji kieruje ks. dr Stanisław Mieszczak SCJ. Działalność Sekcji wyraża się w pracy naukowej i dydaktycznej w różnych jednostkach uniwersyteckich, w aktywnym zaangażowaniu w formację liturgiczną i teologiczną animatorów z Ruchu Światło-Życie, kandydatów do posługi nadzwyczajnego szafarza komunii świętej archidiecezji krakowskiej oraz formacji teologicznej i liturgicznej grup świeckich (np. kursy dla fotografów chcących upamiętniać wydarzenia liturgiczne). Sekcja współpracuje także z Ośrodkiem Formacji Liturgicznej w Zawichoście. Członkowie Sekcji uczestniczą w pracach Komisji Liturgicznej Archidiecezji Krakowskiej, podejmując bieżące tematy i problemy z zakresu życia liturgicznego. Kontynuowana jest współpraca międzynarodowa na poziomie Instytutu Liturgicznego Uniwersytetu Papieskiego Jana Pawła II w Krakowie z Ukraińskim Centrum Liturgicznym we Lwowie i Greckokatolickim Wydziałem Teologicznym Uniwersytetu w Preszowie. Podjęto prace nad stworzeniem praktycznych wytycznych związanych z kultem świętych w naszych parafiach.

Sekcja Sztuki Sakralnej. Sekcją kieruje prof. dr hab. Tomasz Węcławowicz. W minionym roku działalność sekcji koncentrowała na szeroko rozumianej popularyzacji dziedzictwa polskiej sztuki sakralnej w wymiarze zarówno popularnym, jak i naukowym. Członek sekcji o. Mateusz Kawa OCist przez cały rok kontynuował w swym macierzystym klasztorze w Mogile prace nad zorganizowaniem muzeum klasztornego dokumentującego 800 lat dziejów klasztoru wraz z prezentacją zgromadzonych tam przez stulecia dzieł sztuki. Szczegółowa koncepcja muzeum zyskała akceptację Społecznego Komitetu Odnowy Zabytków Krakowa, a w rezultacie przyszłe dofinansowanie 
z Narodowego Funduszu Rewaloryzacji Zabytków Krakowa. Członek sekcji prof. Andrzej Włodarek konsultował prace konserwatorskie w kościele i klasztorze w Staniątkach, a także prowadzi bieżącą inwentaryzację najcenniejszych zachowanych tam zabytków i archiwaliów. W ubiegłym roku prof. Włodarek brał udział w audycjach Polskiego Radia, omawiając sztukę i kulturę duchową staniąteckich benedyktynek, oraz prezentował dzieła klasztorne w trakcie festiwalu Cracovia Sacra 14 i 15 sierpnia. W październiku kierownik sekcji został zaproszony przez przeora klasztoru Dominikanów w Sandomierzu do zespołu konsultacyjno-doradczego. Celem jest opiniowanie prac konserwatorskich i projektowych w planowanej rekonstrukcji kompleksu zabudowań klasztornych, rozebranych po kasacie klasztoru po powstaniu styczniowym. Ponadto w związku z planowanymi na rok 2020 uroczystościami 850 rocznicy śmierci św. Tomasza Becketa kierownik sekcji został zaproszony do Canterbury do wygłoszenia referatu o kulcie tego Biskupa Męczennika w średniowiecznej Polsce.

Sekcja Filoz oficzna. Kierownikiem sekcji jest ks. dr hab. Henryk Majkrzak SCJ. Pierwsze spotkanie Sekcji Filozoficznej w roku sprawozdawczym 2019 odbyło się 27 lutego w krakowskim klasztorze ojców paulinów na Skałce. Omawiano działalność sekcji w bieżącym roku oraz treść artykułów do kolejnego numeru czasopisma „Theofos”. Członek sekcji dr Michał Handzel SPPE prowadził szeroko zakrojoną działalność naukową, wygłaszając wiele referatów: 1 czerwca wystąpił z odczytem nt. Rozwój w miłości przy niepełnosprawności intelektualnej podczas konferencji na temat obecności osób z niepełnosprawnością intelektualną we wspólnocie Kościoła, 15 czerwca wygłosił wykład z historii filozofii nt. Blaski i cienie prywatnego życia filozofów z ASD na Uniwersytecie Mikołaja Kopernika w Toruniu w ramach III Międzynarodowej Konferencji Fundacji Prodeste Autyzm. Światłocienie, 27 września uczestniczył w XVIII Ogólnopolskiej Konferencji Katechetów Szkół Specjalnych w Brennej, głosząc wykład nt. Wsparcie etyczne i religijne osób z ASD - jak wspierać ucznia w spektrum autyzmu? 3 października wystąpił z wykładem o wpływie filozofii Hryhorija Skoworody na personalizm Czesława Bartnika - wykład odbył się w ramach 
Międzynarodowej Konferencji Naukowej w Perejasławiu Chmielnickim (Ukraina). O. dr Michał Handzel opublikował także książkę pt. Teoria poznania samego siebie Hryhorija Sawycza Skoworody. Studium historyczno-filozoficzne (Wydawnictwo Theos-Logos, Głogów-Kraków 2019). Kierownik Sekcji został zaproszony przez dziekan Wydziału Filozofii Katolickiego Uniwersytetu Lubelskiego Jana Pawła II dr hab. Monikę Walczak oraz pracowników Katedry Metafizyki do przygotowania obszernej publikacji do księgi pamiątkowej dedykowanej ks. prof. Andrzejowi Maryniarczykowi SDS z okazji 70 rocznicy jego urodzin oraz 35-lecia pracy naukowej na Katolickim Uniwersytetcie Lubelskim. W dniach 26-27 czerwca odbyło się spotkanie Sekcji Filozoficznej w klasztorze Paulinów na Jasnej Górze. Staraniem Sekcji Filozoficznej ukazał się kolejny czwarty tom rocznika filozoficzno-teologicznego „Theofos”. Dzięki wysiłkom dr Iwony Zogas-Osadnik wydano Triady w obronie świętych hezychastów św. Grzegorza Palamasa (t. 1-2, Wydawnictwo Theos-Logos 2019). Dzieło zostało opatrzone wstępem bpa prof. Ignacego Deca, dra Henryka Paprockiego i s. prof. Teresy Obolevitch.

Sekcja Teologii Fundamentalnej. Kierownikiem sekcji jest ks. dr hab. Damian Wąsek. W roku sprawozdawczym członkowie sekcji organizowali, współorganizowali bądź brali udział w wielu wydarzeniach naukowych o charakterze ekumenicznym i apologetycznym. Do konkretnych owoców działalności zaliczyć należy liczne konferencje, publikacje artykułów naukowych i książek. Najciekawsze z sympozjum nt. Kościół i misja członkowie towarzystwa tworzący Katedrę Eklezjologii zorganizowali w Rzymie (18-19 lutego). Referaty wygłosili m.in. następujący członkowie Sekcji Teologii Fundamentalnej: o. prof. dr hab. Andrzej Napiórkowski OSPPE (Koncepcje Kościoła a realizacja jego misyjności), ks. prof. dr hab. Krzysztof Kościelniak (Misja Kościoła w Azji), ks. dr Józef Morawa (Treść misji Kościoła dzisiaj), ks. dr Paweł Pielka (Posłannictwo kościelne w ujęciu H. U. von Balthasara). To i inne wydarzenia naukowe poprzedzane były spotkaniami i konsultacjami członków sekcji. Równocześnie toczyły się spotkania wokół głównych tematów teologii fundamentalnej. Z najważniejszych 
książkowych publikacji naukowych członków sekcji należy wspomnieć monografie: o. prof. dr hab. Andrzej Napiórkowski, Od Arki Jahwe do Kościoła Trójjedynego Boga (Pelplin 2019) i ks. prof. dr hab. Łukasz Kamykowski, Obraz Izraela i Żydów w myśli chrześcijańskiej. Część II perspektywy (Kraków 2019).

Sekcja Historyczna. Jej pracami kieruje ks. dr Wacław Umiński CM. Członkowie Sekcji Historycznej zorganizowali w roku sprawozdawczym trzy zebrania: 25 października, 28 listopada i 20 grudnia. W czasie pierwszego spotkania w czytelni Biblioteki Zgromadzenia Księży Misjonarzy w Krakowie wysłuchano referatu ks. dr. Wacława Umińskiego CM nt. Stan polskiej prowincji Zgromadzenia Księży Misjonarzy $w$ świetle katalogów z lat 1918-1939. Referent podkreślił, że katalogi te są cennym źródłem informacji zarówno o misjonarzach, jak i dziełach przez nich realizowanych. Poruszono powtórnie kwestię kontynuacji Słownika biograficznego polskich archiwistów kościelnych, którego pierwszy tom został opublikowany przez Wydawnictwo UNUM i jest dostępny online w otwartym dostępie w repozytorium instytucjonalnym Polskiego Towarzystwa Teologicznego (https://doi. org/10.21906/9788376431352), a redaktorzy gromadzą materiały do tomu II. W trakcie drugiego spotkania, również w czytelni Biblioteki Zgromadzenia Księży Misjonarzy w Krakowie, mgr Aneta Kozak wystąpiła z referatem: Świecznik jako element tradycji żydowskiej. Doktorantka Uniwersytetu Papieskiego Jana Pawła II w Krakowie niezwykle kompetentnie przedstawiła przykłady świeczników używanych przez Żydów w minionych wiekach podczas różnych uroczystości. Po referacie wywiązała się ożywiona dyskusja. Trzecie spotkanie sekcji historycznej odbyło się w klasztorze Franciszkanów w Krakowie. Pod przewodnictwem o. Rafała M. Antoszczuka OFMConv uczestnicy zwiedzili najpierw odnowione krużganki klasztorne, a następnie uczestniczyli w spotkaniu opłatkowym połączonym ze śpiewem kolęd.

W okresie sprawozdawczym członkowie sekcji historycznej współorganizowali i brali czynny udział w kilku sympozjach i konferencjach. W dniach 24-26 kwietnia odbył się w Krakowie XXI Ogólnopolski 
Zjazd Studentów Archiwistyki współorganizowany przez Katedrę Archiwistyki i Nauk Pomocniczych Historii Uniwersytetu Papieskiego Jana Pawła II w Krakowie. Zjazd został objęty patronatem Polskiego Towarzystwa Teologicznego. Członkowie sekcji podczas zjazdu służyli swoją pomocą, prowadząc m.in. niektóre panele dyskusyjne.

24 maja odbyła się w Krakowie ogólnopolska konferencja naukowa nt. Ukryte perły archiwistyki zorganizowana przez Katedrę Archiwistyki i Nauk Pomocniczych Historii Uniwersytetu Papieskiego Jana Pawła II w Krakowie oraz Sekcję Historyczną. Podczas konferencji referaty wygłosili następujący członkowie sekcji: ks. prof. dr hab. Józef Marecki, Archiwa skarbnica przeszłości, ks. dr Wacław Umiński CM, Materiały do dziejów zakładów Jadwigi Generałowej Zamoyskiej w zasobach Archiwum Instytutu Wydawniczego „Nasza Przeszłość”, mgr Adrian Cieślik, „Okruszyny biograficzne o niektórych znakomitych ojcach Zakonu Kaznodziejskiego" brata Kazimierza Jucewicza OP, czyli próba biografistyki dominikańskiej z przełomu XIX i XX w.

W dniach 30-31 maja podczas ogólnopolskiej konferencji naukowej w Gnieźnie poświęconej pierwszej pielgrzymce Jana Pawła II do Polski referaty wygłosili następujący członkowie sekcji: ks. prof. dr hab. Józef Marecki, Najważniejsze wątki papieskiego nauczania $w$ trakcie pobytu w Krakowie, ks. dr Wacław Umiński CM, Reakcje duchowieństwa i wiernych na wizytę papieska $w$ Krakowie.

Podczas V ogólnopolskiej konferencji naukowej z cyklu Historia Pamięć - Tożsamość zorganizowanej przez Instytut Historii i Archiwistyki Uniwersytetu Pedagogicznego w Krakowie w dniach 13-14 listopada referat pt. „Trwała ruina” jako element kształtujacy krajobraz kulturowy wygłosiła dr hab. Lucyna Rotter.

Członkowie sekcji historycznej ks. prof. Józef Marecki, ks. dr Wacław Umiński CM, mgr Marcin Rdzak uczestniczą w realizacji projektu poświęconego księciu Adamowi Stefanowi Sapiesze, który swoją działalnością oraz postawą w pierwszej połowie XX wieku zasłużył sobie na miano Wielkiego Jałmużnika i Księcia Niezłomnego. Zadanie numer 0046/2019 zostało sfinansowane w ramach programu Ministerstwa Nauki i Szkolnictwa Wyższego pod nazwą Dialog w latach 2019-2020. 
Sekcja Teologii Życia Konsekrowanego. Sekcja działa pod kierunkiem s. dr hab. Adelajdy Sielepin CHR, prof. UPJPII. Działalność sekcji realizuje się w dwóch nurtach: zespołowym i indywidualnym. $\mathrm{W}$ ramach tego pierwszego odbyły się 3 zebrania naukowe w dniach 26 czerwca, 9 października i 4 grudnia. W roku sprawozdawczym podjęta została problematyka relacji teologii charyzmatu do życia konsekrowanego. Członkowie sekcji przygotowywali referaty dotyczące szczegółowych zagadnień, takich jak charyzmat i powołanie, charyzmat założycielski, charyzmat pierwszego pokolenia, charyzmat instytutu i charyzmaty funkcjonalne. Każde spotkanie obejmowało referat i dyskusję, a także wymianę na temat bieżących wydarzeń, które odnoszą do postaw człowieka konsekrowanego. Ponadto kontynuowane były prace redakcyjne serii Ewangelia - Proroctwo - Nadzieja nad opublikowaniem II tomu zatytułowanego Konsekracja i świat pod redakcją s. Adelajdy Sielepin i ks. Kazimierza Wójtowicza. Natomiast w ramach działalności indywidualnej członków widoczna jest duża aktywność na poszczególnych polach naukowo-formacyjnych. Ogółem opublikowano kilkanaście artykułów i dwie książki autorstwa s. Bogny Młynarz pt. W Jego ranach. Droga krzyżowa - miejsce uzdrowienia oraz druga w formie wywiadu pt. To Bóg szuka człowieka, która została wydana także w 2019 roku w języku chorwackim pt. Bog trazi covjeka. Ukazała się publikacja zbiorowa pt. Duch Święty źródłem doskonałości życia zakonnego. Program formacji stałej na rok 2019 (Kraków 2019) pod redakcją ks. dr. Eugeniusza Ziemanna SCJ. W przygotowaniu jest monografia na temat relacji teologii charyzmatu do konsekracji autorstwa ks. Kazimierza Wójtowicza. Zostało przeprowadzonych 6 serii rekolekcji do osób konsekrowanych, kilkadziesiąt konferencji w czasie dni skupienia we wspólnotach konsekrowanych, a także dla młodzieży, ponadto systematycznie prowadzone są wykłady w ramach formacji wstępnej lub permanentnej.

Sekcja Syndonologiczna. Sekcja powstała 21 maja 2014 ze Studium Syndonologicznego prowadzonego przez wiele lat przez ks. doc. dra hab. Jerzego Chmiela. Sekcję prowadzi ks. mgr lic. Piotr Listopad. Sekcja nie złożyła sprawozdania. 


\section{Działalność oddziałów terenowych}

Oddział w Katowicach. Pracami oddziału liczącego obecnie 21 członków kieruje ks. dr hab. Andrzej Nowicki. W roku sprawozdawczym członkowie oddziału spotkali się dwukrotnie w auli domu parafialnego Świętych Apostołów Piotra i Pawła w Katowicach. Pierwsze ze spotkań 19 marca zgromadziło - oprócz członków Polskiego Towarzystwa Teologicznego - licznie przybyłych przedstawicieli świata kultury i mediów. W ramach tego spotkania wykład nt. Symbolika Serca Jezusowego w Ewangelii św. Jana 19, 37 wygłosił ks. prof. Józef Kozyra. Drugie spotkanie odbyło się 10 września. W jego trakcie wykład nt. Erich Przywara - teolog pogranicza i dialogu wygłosił ks. dr hab. Andrzej Nowicki. W spotkaniach oddziału katowickiego bierze także udział zainteresowane grono studentów teologii i zaproszeni goście.

Oddział w Częs t o ch owie. Pracami oddziału kieruje ks. dr hab. Paweł Maciaszek. W roku 2019 odbyły się 4 spotkania zarządu oddziału częstochowskiego (10 stycznia, 21 lutego, 8 maja, 4 października, 16 listopada). Zasadniczym ich tematem była organizacja ogólnopolskiej konferencji naukowej pt. Aktualne wyzwania teologii oraz ogólnopolskiego sympozjum katechetycznego pt. Eucharystia - tajemnica wyznawana na katechezie. Przygotowywana od kilku miesięcy konferencja odbyła się w Częstochowie 9 maja 2019 roku w gmachu Wyższego Seminarium Duchownego i Wyższego Instytutu Teologicznego. Wzięło w niej udział 41 prelegentów, do których należeli doświadczeni teologowie (samodzielni pracownicy naukowi), jak i uczący się uprawiania teologii (doktoranci i licencjaci). Przedstawiający referaty reprezentowali następujące uczelnie: Uniwersytet Papieski Jana Pawła II w Krakowie, Uniwersytet Kardynała Stefana Wyszyńskiego, Katolicki Uniwersytet Lubelski Jana Pawła II, Uniwersytet Opolski, Uniwersytet WarmińskoMazurski, Uniwersytet Śląski w Katowicach, Akademia Ignatianum w Krakowie. Konferencja składała się z dwóch części: w pierwszej wspólnej dla wszystkich wygłoszone zostały referaty z zakresu teologii moralnej, duchowości i fundamentalnej, w drugiej odbywającej się w grupach tematycznych uczestnicy wysłuchali co najmniej 
4 prezentacji. Uczestnikami konferencji byli także klerycy diecezji częstochowskiej i sosnowieckiej, grupa studentów Wyższego Instytutu Teologicznego, kilkunastu katechetów oraz członkowie oddziału częstochowskiego. Konferencję rozpoczęła msza święta, której przewodniczył i homilię wygłosił metropolita częstochowski abp Wacław Depo, będący także członkiem Polskiego Towarzystwa Teologicznego.

Oddział częstochowski był także współorganizatorem sympozjum katechetycznego Eucharystia - tajemnica wyznawana na katechezie. W składającym się z 2 sesji spotkaniu, które odbyło się w Częstochowie 30 listopada 2019 roku, udział wzięli katecheci archidiecezji częstochowskiej, sosnowieccy i częstochowscy klerycy oraz studenci Wyższego Instytutu Teologicznego w Częstochowie. Wymienieni uczestnicy wysłuchali referatów prelegentów z takich ośrodków naukowych jak Uniwersytet Papieski Jana Pawła II w Krakowie, Katolicki Uniwersytet Lubelski Jana Pawła II, Uniwersytet Śląski w Katowicach, Akademia Ignatianum w Krakowie, Wyższy Instytut Teologiczny Księży Misjonarzy w Krakowie. W programie sympozjum znalazła się także msza święta, której przewodniczył i homilię wygłosił abp Wacław Depo.

Ponadto 19 lutego w Krakowie odbyło się spotkanie członków oddziału częstochowskiego, w którym wzięło udział 14 osób. Przebieg spotkania wyznaczyły następujące treści: referat ks. mgra lic. Bartłomieja Bardelskiego pt. Duszpasterska odpowiedzialność proboszcza za katechizację w świetle obowiąujących dokumentów Kościoła i dyskusja (wywołana treściami prezentacji) na temat wypełniania przez duszpasterzy prawnych norm dotyczących katechizacji oraz podział pracy związanej z przygotowaniem i przebiegiem naukowej konferencji w dniu 9 maja 2019. W roku sprawozdawczym do częstochowskiego oddziału Polskiego Towarzystwa Teologicznego przyjętych zostało 3 nowych członków. Są to: ks. dr Wojciech Kućko, s. dr M. Iwona Kopacz PDDM i ks. mgr lic Bartłomiej Bardelski.

Oddział w Pr ze myślu. Pracami oddziału liczącego 36 członków kieruje ks. dr hab. Wacław Siwak. W trakcie sympozjum historyczno-mariologicznego nt. Consolatio Populi Prevorscensis. Z dziejów kultu Matki Bożej Pocieszenia $w$ kościele Bernardynów w Przeworsku kierownik 
oddziału wygłosił w dniu 25 maja referat pt. Koronacja wizerunku Przeworskiej Matki Bożej Pocieszenia. Sens teologiczny. 26 października w Muzeum Ziemi Leżajskiej ks. dr hab. Wacław Siwak przewodniczył sesji historyczno-naukowej pt. Jubileusz 400-lecia konsekracji kościoła farnego pw. Świętej Trójcy w Leżajsku. Natomiast 29 października kierownik oddziału wziął udział w panelu: $W$ poszukiwaniu form kultu Bożego miłosierdzia w ramach konferencji teologicznej pt. Rosarium Misericordiae zorganizowanej przez Katedrę Pneumatologii, Eklezjologii i Mariologii w Katolickiego Uniwersytetu Lubelskiego Jana Pawła II.

W roku sprawozdawczym odbył się I Kongres Biblijny Archidiecezji Przemyskiej pod hasłem: Panie, uświęć nas w prawdzie. Spotkania kongresowe miały miejsce w Polańczyku (21 września), Strachocinie (5 października), Łańcucie (12 października), Jarosławiu (19 października), Krośnie (26 października) i w Przemyślu (9 listopada). Powstał on z inicjatywy ks. dra hab. Stanisława Haręzgi, moderatora Dzieła Biblijnego Archidiecezji Przemyskiej, członka Polskiego Towarzystwa Teologicznego. Prelegenci poszczególnych spotkań podejmowali tematykę związaną z zagadnieniem prawdy. M.in. ks. dr Norbert Podhorecki, sekretarz oddziału przemyskiego, wygłosił 9 listopada 2019 w Przemyślu referat pt. Zagadnienie prawdy w perspektywie współczesności. Wyżej wyszczególnione sympozja i konferencje stały się okazją do spotkań członków oddziału przemyskiego i prezentacji ich dokonań naukowych.

W roku sprawozdawczym członkowie oddziału przemyskiego wydali 18 tom „Premislia Christiana”, kilka książek, artykułów naukowych i recenzji. Prowadzili także wykłady w ramach studiów licencjackich z teologii dla prezbiterów: ks. dr Norbert Podhorecki: Chrześcijańska myśl filozoficzno-teologiczna wobec wyzwań wspótczesności, ks. dr hab. Stanisław Haręzga: Odnowa biblijna parafii oraz ks. dr Waldemar Janiga: Katecheza dzisiaj. Problemy teologiczne, kulturowe i prawne oraz Potencjał ewangelizacyjny rekolekcji szkolnych.

Oddział w Kalwarii Zebrzydowskiej. Pracami oddziału kieruje o. dr Roland Pancerz OFM, rektor Wyższego Seminarium Duchownego Ojców Bernardynów, przy którym działa oddział Polskiego Towarzystwa Teologicznego. W roku sprawozdawczym 19 listopada oddział 
kalwaryjski we współpracy z seminarium duchownym w Kalwarii Zebrzydowskiej zorganizował sympozjum nt. Franciszkańska działalność misyjna $w$ stużbie Ewangelii. W jego trakcie wygłoszone zostały następujące referaty: Franciszkański misjonarz brat Celestyn Mieczysław Moszyński (dr Tomasz Szymczak OFMConv), Świątobliwi misjonarze franciszkańscy historycznego terytorium obejmującego obecna Prowincję św. Maksymiliana Kolbego w Polsce (mgr Zbigniew Joskowski OFMConv), Misje w Afryce Środkowo-Wschodniej (dr Placyd Górka OFM), Wspomnienia bernardyńskiego misjonarza w Ziemi Świętej o. Norberta Golichowskiego OFM 1848-1921 (dr Aleksander Sitnik OFM) oraz Życie, działalność i obecność bernardynów w Martin Coronado $w$ Argentynie (mgr lic. Marceli Ryszard Gęśla OFM).

Oddział w Tu ch owie.Pracami oddziału kieruje o.dr Maciej Sadowski CSsR. Członkowie oddziału odbyli w roku sprawozdawczym 3 zebrania 22 lutego, 26 czerwca oraz 5 października. Oddział tuchowski opierał się na kadrze naukowo-pedagogicznej tutejszego Wyższego Seminarium Duchownego Redemptorystów. W gronie profesorskim tuchowskiego oddziału w mijającym roku sprawozdawczym było aktywnych 36 redemptorystów, w tym 3 profesorów zwyczajnych i 4 doktorów habilitowanych.

Członkowie oddziału tuchowskiego opublikowali w minionym roku 5 publikacji książkowych, 45 artykułów naukowych i popularnonaukowych, 16 recenzji, w tym recenzje wydawnicze czasopism i monografii oraz dorobku naukowego i prac doktorskich. Brali udział w kilkudziesięciu audycjach radiowych i telewizyjnych różnych stacji i rozgłośni ogólnopolskich. Gościli na 34 sympozjach i zjazdach, przy czym w 7 przypadkach byli ich organizatorami. Wygłosili też 13 referatów. Jeden z wykładowców, utalentowany muzycznie, dał 23 koncerty wokalne.

W roku sprawozdawczym Oddział w Tuchowie był współorganizatorem dorocznego sympozjum naukowego nt. Matżeństwo i rodzina (25-27 lutego) w ramach formacji stałej pogłębiającej duchowość apostolską w perspektywie działalności misyjno-rekolekcyjnej. W jego trakcie ks. Bogusław Kempa z Kalisza wygłosił referaty: Św. Józef- patron na nasze czasy oraz Św. Józef - apostoł życia i rodziny, ks. Zbigniew Rutkowski z Gniewu przedstawił ciekawe pomysły kreatywnego 
głoszenia kazań podczas rekolekcji dla dzieci i młodzieży, a prof. Paweł Mazanka CSsR podzielił się filozoficzno-teologicznymi refleksjami na temat cnoty nadziei i ukazał postać o. Bernarda Łubieńskiego CSsR jako misjonarza nadziei. Warto wspomnieć, iż co roku polscy redemptoryści prowadzą ok. 100 misji parafialnych, podobną liczbę renowacji i około 700 rekolekcji parafialnych, kapłańskich, zakonnych, powołaniowych i dla różnych grup świeckich.

W dniach 4-6 listopada w Lubaszowej odbyły się warsztaty homiletyczne nt. Eucharystia daje życie. 40 redemptorystów z Polski i zagranicy uczestniczyło w serii wykładów z zakresu homiletyki autorstwa ks. prof. Daniela Brzezińskiego, wykładowcy liturgiki i homiletyki na Uniwersytecie Mikołaja Kopernika w Toruniu. Prelekcje te stały się inspiracją do prac w grupach, gdzie wypracowywano konkretne schematy kazań rekolekcyjnych. Wraz z członkami zarządu Warszawskiej Prowincji Redemptorystów misjonarze omówili aktualne sprawy misji parafialnych i rekolekcji w Polsce.

19 listopada odbyło się w Tuchowie sympozjum naukowe nt. Św. Gerard Majella na straży prawego sumienia i świętości życia. Jego współorganizatorem była krakowska Oficyna Wydawnicza Homo Dei. Uczestnicy sympozjum wysłuchali następujących referatów: Słabość i wina. Kulturowo-antropologiczne aspekty doświadczenia wyrzutów sumienia (dr Maciej Zinkiewicz OFMCap z Krakowa), Obrona sumienia ocaleniem człowieka (ks. dr hab. Zbigniew Wanat z Torunia), Jak formowała się dzisiejsza forma sakramentu pokuty? (ks. prof. Marek Starowieyski z Warszawy), Św. Gerard Majella-patron rodzacego się życia (Ewa Kowalewska z Gdańska) oraz Czy duchowe przesłanie św. Gerarda Majelli aktualne jest także dziś (Piotr Chyła CSsR z Rzymu).

Oddział tuchowski zainicjował w minionym roku sprawozdawczym cykl otwartych wykładów gościnnych w ramach Tuchowskiego Forum Lektury Współczesności DIA-LOGOS. W ramach forum 25 października w auli Wyższego Seminarium Duchownego prof. Aleksander Nalaskowski z Torunia wygłosił wykład: Czy zdążymy zbudować Arkę przed nowym potopem? Wychowanie. Rodzina. Przyszłość.

Z działalności Oddziału w Tuchowie w roku sprawozdawczym należy także odnotować wykład inauguracyjny w Wyższym Seminarium 
Duchownym Redemptorystów w Tuchowie nt. Czy warto jeszcze studiować teologię? wygłoszony 5 października przez o. prof. dra hab. Witolda Kaweckiego (Uniwersytet Kardynała Stefana Wyszyńskiego).

Staraniem Oddziału w Tuchowie ukazał się 17 tom rocznika „Studia Redemptorystowskie. Pismo naukowe Warszawskiej Prowincji Redemptorystów”, któremu na liście czasopism punktowanych ministra nauki i szkolnictwa wyższego przyznano 20 punktów.

Oddział w Kielcach. Pracami oddziału kieruje ks. dr Paweł Borto. W roku sprawozdawczym oprócz comiesięcznych spotkań członkowie oddziału kieleckiego wzięli aktywny udział w konferencji naukowej Paradygmaty, style myślenia, programy badawcze.Jak zmieniają się nauki? zorganizowanej 22 maja przez Wyższe Seminarium Duchowne w Kielcach i Instytut Historii Uniwersytetu Jana Kochanowskiego. Prelegentami trzech interesujących sesji naukowych byli naukowcy z Cambridge University (Trinity Hall), Katolickiego Uniwersytetu Lubelskiego, Uniwersytetu Jana Kochanowskiego, Uniwersytetu Kardynała Stefana Wyszyńskiego, Uniwersytetu Papieskiego Jana Pawła II w Krakowie i Wyższego Seminarium Duchownego w Kielcach. W swoich odczytach poruszyli oni następujące zagadnienia: Absconditeizm jako program badawczy teologii naturalnej, Antyczne a wspótczesne wyniki obserwacji zachowania zwierzat. Paradygmat humanistyczny versus przyrodniczy, Inny wszechświat - próby rozwiąania kryzysu wspótczesnej kosmologii teoretycznej, Jak nie pisać o powstaniach narodowych, Przemiany paradygmatów uprawiania filozoficznej mediewistyki, Nauka o krwi. Przemiany paradygmatu do końca XVIII wieku, Od astronomii do astrologii i z powrotem. Rozważania mediewisty, Od idei samorództwa i kosmicznego pochodzenia życia do bilinearnych teorii biogenezy, Od Wszechświata statycznego do ekspandującego - zmiana paradygmatu czy stylu myślenia?, Zmiana paradygmatu to nie zmiana zasad i wartości moralnych. Konferencja zakończyła się dyskusją panelową prelegentów.

Ponadto trzech członków kieleckiego oddziału uzyskało w roku sprawozdawczym stopień naukowy doktora habilitowanego: ks. Jarosław Czerkawski i ks. Tomasz Siemieniec w dziedzinie nauk teologicznych, natomiast ks. Rafał Dudała w dziedzinie nauk społecznych. 
Oddział w Sandomierzu. Pracami oddziału kieruje ks. dr hab. Roman Bogusław Sieroń, prof. KUL. Oddział liczy 30 osób i działa przy Instytucie Teologicznym im. bł. Wincentego Kadłubka w Sandomierzu. W roku sprawozdawczym oddział sandomierski podjął wiele form działalności. Członkowie oddziału współorganizowali i brali udział w czterech konferencjach naukowych. Były to: sympozjum towarzyszące zjazdowi Federacji Bibliotek Kościelnych FIDES (Sandomierz, 4-6 września), 8 support akademicki zatytułowany: „Społeczeństwo i Rodzina”- kwartalnik Wydziału KUL w Stalowej 2004-2019: historia, dzień dzisiejszy, perspektywy - konteksty polskie i zagraniczne (Stalowa Wola, 29 listopada), Ogrody przykościelne - teoria i praktyka (Katolicki Uniwersytet Lubelski Jana Pawła II oraz Kuria Diecezjalna w Sandomierzu, Sandomierz, 14 grudnia) oraz zwyczajne posiedzenie wiosenno-letnie Oddziału w Sandomierzu, na którym wykład Wyzwania dla nauki polskiej w kontekście reformy „Konstytucja dla Nauki 2.0” wygłosił kierownik oddziału ks. dr hab. Roman B. Sieroń, prof. KUL (Sandomierz, 2 kwietnia).

Członkowie oddziału sandomierskiego wzięli również udział w 9 krajowych i zagranicznych konferencjach naukowych, wygłaszając referaty, prowadząc obrady bądź w nich uczestnicząc. Prowadzono także wzmożoną działalność wydawniczą, czego owocem jest ukazanie się 15 publikacji książkowych i artykułów naukowych zamieszczonych w „Rocznikach Teologicznych” oraz w kwartalniku „Społeczeństwo i Rodzina” redagowanym przez kierownika oddziału.

Oddział w Tarnowie. Kierownikiem oddziału jest ks. prof. dr hab. Janusz Królikowski. Oddział nie złożył sprawozdania.

Oddział w Rzeszowie. Kierownikiem oddziału jest ks. dr hab. Andrzej Garbarz, prof. UR. W roku 2019 członkowie Polskiego Towarzystwa Teologicznego Oddziału w Rzeszowie prowadzili działalność naukowo-dydaktyczną w Wyższym Seminarium Duchownym w Rzeszowie, w Instytucie Teologiczno-Pastoralnym, na Uniwersytecie Rzeszowskim, na Politechnice Rzeszowskiej oraz w Wyższej Szkole Informatyki i Zarządzania w Rzeszowie. Członkowie oddziału uczestniczyli w wielu 
szkoleniach, konferencjach i sympozjach. Współpracowali z Wydziałem Katechetycznym Kurii Diecezjalnej w Rzeszowie, Kuratorium Oświaty w Rzeszowie oraz z rzeszowskim oddziałem Civitas Christiana. 27 lutego w Instytucie Teologiczno-Pastoralnym im. św. Józefa Sebastiana Pelczara w Rzeszowie odbył się Diecezjalny Etap XXIX Olimpiady Teologii Katolickiej. Uczestniczyło w nim 150 uczniów. Komisję tworzyli członkowie towarzystwa. 14 marca odbyła się konferencja naukowa Nauka społeczna Kościoła wobec dylematów XXI wieku. Konferencję zorganizowały wspólnie Instytut Teologiczno-Pastoralny, Wyższe Seminarium Duchowne w Rzeszowie, Akcja Katolicka i Civitas Christiana Oddział w Rzeszowie. 28 kwietnia odbył się w Instytucie Teologiczno-Pastoralnym XXIII Etap Finału Diecezjalnego Ogólnopolskiego Konkursu Wiedzy Biblijnej zorganizowany przez Civitas Christiana. Koordynatorem imprezy był członek towarzystwa Krzysztof Dziduch z Civitas Christiana, a Komisji konkursowej przewodniczył ks. dr Marek Dzik, moderator Dzieła Biblijnego w Diecezji Rzeszowskiej. W konkursie wzięło udział 150 osób. 14 września obchodzono jubileusz pięciolecia Uniwersytetu Trzeciego Wieku Diecezji Rzeszowskiej. Od nowego roku akademickiego funkcję rektora po ks. dr. Marku Dziku przejął ks. dr hab. Jerzy Buczek. Odnotować należy także dwa ważne wydarzenia o zasięgu ogólnopolskim. W dniach 2-4 września w Instytucie Teologiczno-Pastoralnym odbyła się 55. Ogólnopolska Konferencja Rektorów Wyższych Seminariów Duchownych Diecezjalnych i Zakonnych, a w dniach 17-19 września odbył się XX Zjazd Stowarzyszenia Polskich Muzyków Kościelnych. We wszystkich wymienionych działaniach aktywnie uczestniczyli członkowie oddziału. Poza tym opublikowali oni szereg tekstów, zwłaszcza popularnonaukowych w diecezjalnej prasie oraz prowadzili audycje w Katolickim Radiu VIA.

Oddział w Bielsku-Białej. Kierownikiem oddziału jest ks. dr hab. Robert Samsel. Oddział liczy aktualnie 45 członków i działa w siedzibie kurii diecezji bielsko-żywieckiej w Bielsku-Białej przy ul. Żeromskiego 5a. W roku sprawozdawczym pierwsze spotkanie członków połączone było z opłatkiem dla środowiska akademickiego diecezji bielsko-żywieckiej zorganizowanym w Kurii Diecezjalnej 17 stycznia 2019 roku. Homilię 
w czasie mszy świętej wygłosił bp prof. dr hab. Roman Pindel. W roku sprawozdawczym odbyło się 8 cyklicznych, comiesięcznych spotkań o tematyce biblijnej. Prócz członków towarzystwa uczestniczyli w nich także słuchacze Uniwersytetu Trzeciego Wieku Akademii TechnicznoHumanistycznej w Bielsku-Białej oraz Akademii Seniora w Bielsku-Białej, a także wolni słuchacze. Spotkania prowadził o. dr Jan E. Urbański.

Oddział w Rad omiu. Kierownikiem oddziału jest ks. prof. dr hab. Marek Jagodziński. W roku sprawozdawczym oddział był współorganizatorem ogólnopolskiej konferencji naukowej pt. Wiara i rozum dzisiaj. Encyklika „Fides et ratio” wobec wyzwań wspótczesnego świata, która odbyła się 15 listopada w Wyższym Seminarium Duchownym w Radomiu. W sesji pierwszej wysłuchano następujących referatów: Wiara i rozum czy rozum i wiara - pytanie o pierwszeństwo: Anzelm z Canterbury i Jan Paweł II (prof. dr hab. Maciej Manikowski, Uniwersytet Wrocławski), Błogosławiony ołów obciążający pośpiesznie wzbijające się do lotu (acz nieuksztaltowane) skrzydła... Czyli o potrzebie racjonalnej, krytycznej i powściagliwej refleksji nad relacjami między rozumem a wiara - ratio et fides $i$ wiara a rozumem - fides et ratio (dr hab. Marek Rębierz, Uniwersytet Śląski), Spór (dialog) między wiara a rozumem jako element konstytutywny rozwoju nauki (dr hab. Wiesław Wójcik, Uniwersytet Humanistyczno-Przyrodniczy im. Jana Długosza w Częstochowie). Natomiast w sesji drugiej przybliżono następujące zagadnienia: Sztuczna inteligencja - od idei do transformacji rzeczywistości (ks. dr hab. Józef Kloch, prof. Uniwersytetu Kardynała Stefana Wyszyńskiego), Encyklika „Fides et ratio” - w kierunku prawdy integralnej (ks. prof. dr hab. Marek Jagodziński, Katolicki Uniwersytet Lubelski Jana Pawła II) oraz Rozum i wiara a kultura $w$ świetle encykliki „Fides et ratio” (ks. dr Wojciech Wojtyła, Uniwersytet Technologiczno-Humanistyczny im. Kazimierza Pułaskiego w Radomiu).

Oddział w S o s now cu. Kierownikiem oddziału liczącego aktualnie 37 członków jest ks. prof. dr hab. Jan Orzeszyna. W roku sprawozdawczym odbyły się łącznie dwa spotkania, w tym jeden dzień skupienia połączony z sympozjum naukowym i jedno spotkanie organizacyjne. 
To ostatnie poświęcone zaplanowaniu pracy oddziału w roku akademickim 2019/2020 miało miejsce 31 sierpnia 2019 roku. W jego trakcie wykład nt. Nie służymy sprawie przegranej. Blaski i cienie posługi katechetycznej wygłosił ks. prof. dr hab. Marian Zając (Katolicki Uniwersytet Lubelski Jana Pawła II).

Wielkopostny dzień skupienia (6 kwietnia) z udziałem bpa dra Grzegorza Kaszaka oraz członków i sympatyków Oddziału w Sosnowcu odbył się w budynku Wydziału Katechetycznego Kurii Diecezjalnej w Sosnowcu. W jego trakcie oprócz Eucharystii zostały wygłoszone następujące wykłady: Znaczenie i rola katechezy mistagogicznej we współczesnym nauczaniu religii (ks. dr hab. Roman Buchta, prof. Uniwersytetu Śląskiego), Tożsamość młodzieży w niewoli popkultury (dr hab. Marek Walancik, prof. Akademii WSB), Przygotowanie do wysitku - zapomniana treść edukacji (dr hab. Eugenia Rostańska, prof. Akademii WSB), Mądrość i duchowość jako szczególne wartości dla wspótczesnego człowieka (dr hab. Janusz Morbitzer, prof. Akademii WSB). Całość obrad podsumował ks. dr Michał Borda. Oddział sosnowiecki owocnie współpracuje z Akademią WSB w Dąbrowie Górniczej. Warto nadmienić, że z okazji świąt wielkanocnych i bożonarodzeniowych zarząd oddziału sosnowieckiego tradycyjnie wysyła życzenia wszystkim swoim członkom.

Oddział w Szczecinie. Kierownikiem oddziału działającego przy Wydziale Teologicznym Uniwersytetu Szczecińskiego jest ks. inf. prof. dr hab. Andrzej Offmański. W roku sprawozdawczym oddział szczeciński zorganizował 3 konferencje naukowe, które cieszyły się dużym zainteresowaniem. Pierwsza z nich 16 marca poświęcona była zagadnieniu: Kościół woła o dynamizm nowej ewangelizacji. Wysłuchano pięciu referatów: Jak ożywić nowa ewangelizację? (ks. prof. dr hab. Andrzej Offmański), Pielgrzymowanie forma ewangelizowania (ks. dr Paweł Płaczek), Światowe Dni Młodych „dotknięciem” ewangelizacji (ks. dr Marcin Szczodry), Współczesne problemy z tożsamością Kościoła (ks. prof. Tadeusz Czapiga) oraz Upodmiotowienie laikatu odejściem od modelu Kościoła klerykalizowanego (ks. dr Kazimierz Półtorak, Szczecin-Gryfice).

W dniach 10-11 czerwca odbyły się w Trzęsaczu XVI Nadbałtyckie Debaty Katechetyków Polskich - konferencja naukowa zorganizowana 
przez Katedrę Katechetyki Wydziału Teologicznego Uniwersytetu Szczecińskiego wraz z Oddziałem Szczecińskim Polskiego Towarzystwa Teologicznego. Tym razem były one poświęcone problemowi świętości. Podstawę obrad stanowiła adhortacja apostolska papieża Franciszka Gaudete et exsultatae o powołaniu do świętości w świecie współczesnym. Znawcy problematyki świętości z całej Polski przedstawili to zagadnienie z punktu widzenia teologii duchowości, patrologii i duszpasterstwa, biblistyki i katechetyki. Drugi dzień obrad poświęcony był ujęciu teologiczno-katechetycznemu i pedagogiczno-katechetycznemu świętości.

Oddział w Szczecinie kontynuował także cykl otwartych wykładów pt. Ocalić od zapomnienia. 22 listopada odbyła się czwarta już edycja tego cyklu mająca na celu upamiętnienie pionierów Kościoła nad Odrą i Bałtykiem. Tym razem była ona poświęcona związkom kard. Stefana Wyszyńskiego z archidiecezją szczecińsko-kamieńską. Podjęta w tym roku tematyka miała służyć dobremu przygotowaniu do zbliżającej się beatyfikacji Prymasa Tysiąclecia i jubileuszu 50-lecia ustanowienia struktur kościelnych na Ziemiach Zachodnich i Północnych. W trakcie sesji przybliżone zostały następujące tematy: Kard. Stefan Wyszyński „święty szczeciński” (referował ks. prał. dr Aleksander Ziejewski), Proces beatyfikacyjny Prymasa w Szczecinie i w Warszawie (referował ks. inf. dr Ryszard Ziomek), Stuga Boży a Ziemie Zachodnie Polski (referował ks. prof. dr hab. Grzegorz Wejman). W posiedzeniu tym udział wziął bp Henryk Wejman, 25 członków towarzystwa oraz kilkanaście zainteresowanych osób.

Oddział w Toruniu. Pracami oddziału kieruje ks. prof. dr. hab. Dariusz Zagórski. W roku sprawozdawczym Oddział w Toruniu zorganizował 2 spotkania naukowe: 5 lutego z referatem kierownika oddziału nt. Eucharystia w nauczaniu Ojców Kościoła oraz 8 listopada z referatem ks. Wojciecha Cichosza nt. Wspótczesne dylematy edukacyjne. Przygotowywana jest konferencja naukowa nt. Theological and ethical issues concerning $A I$.

Oddział we Włocławku. Kierownikiem oddziału jest ks. dr hab. Lech Król. W roku sprawozdawczym odbyły się cztery spotkania w Wyższym Seminarium Duchownym we Włocławku. Trzy z nich 
21 lutego, 10 października i 7 listopada miały charakter wykładów otwartych. Pierwsze spotkanie poświęcone było setnej rocznicy założenia placówki Zgromadzenia Sióstr Franciszkanek Rodziny Maryi we Włocławku. Z problematyką tą zapoznała uczestników s. dr Antonietta Frącek w swoim referacie zatytułowanym Włocławska placówka Sióstr Franciszkanek Rodziny Maryi na tle dziejów zgromadzenia. W 100 rocznicę założenia. Drugie spotkanie rozpoczęło trzydniowe obchody jubileuszu 450 rocznicy założenia Wyższego Seminarium Duchownego we Włocławku. Prelegentem był wybitny biblista ks. prof. dr hab. Waldemar Chrostowski (Uniwersytet Kardynała Stefana Wyszyńskiego), który wystąpił z referatem: Jubileusz w perspektywie biblijnej. Trzecie spotkanie oddziału, mające charakter wykładu otwartego, odbyło się w 80 rocznicę aresztowania przez Niemców bł. biskupa Michała Kozala, profesorów i alumnów Wyższego Seminarium Duchownego oraz nauczycieli szkół włocławskich. Problematykę tę przybliżył wykład ks. prof. Tomasza Kaczmarka pt. Prześladowanie duchowieństwa katolickiego przez totalitarny system narodowego socjalizmu Hitlera - „misterium iniquitatis”. W wykładach otwartych uczestniczyli członkowie towarzystwa, osoby życia konsekrowanego, alumni Wyższego Seminarium Duchownego, świeccy Włocławka i okolicy. Zarząd oddziału towarzystwa, nawiązując kontakty ze szkołami miasta i okolicy, zapraszał też na powyższe spotkania nauczycieli i katechetów oraz członków różnych ruchów parafialnych. Należy zauważyć, że wykłady otwarte cieszą się coraz większą popularnością społeczeństwa Włocławka.

Odmienny charakter miało spotkanie członków oddziału w dniu 18 czerwca. Było ono dwuczęściowe. Najpierw po zapoznaniu się ze sprawozdaniami udzielono absolutorium odchodzącemu zarządowi i wybrano nowy w tym samym składzie na trzecią kadencję. Druga część posiedzenia miała charakter czysto naukowy i była dedykowana ks. prof. Januszowi Gręźlikowskiemu z okazji 65 rocznicy jego urodzin. W trakcie posiedzenia uczestnicy wysłuchali odczytu ks. prof. dr hab. Wojciecha Góralskiego (Uniwersytet Kardynała Stefana Wyszyńskiego) na temat 450-lecia powołania do istnienia Seminarium Duchownego we Włocławku.

Nadto zarząd podtrzymywał kontakty z Włocławskim Towarzystwem Naukowym, które 14 czerwca 2019 roku świętowało jubileusz 40-lecia 
swojego powstania. Z tej okazji odznaczyło ono oddział włocławski srebrnym medalem. Na jednym z jego posiedzeń 15 kwietnia ks. Lech Król wygłosił wykład pt. Dzieła dobroczynne w Polsce po 1918 r. na przykładzie działalności św. Józefa Sebastiana Pelczara. Oddział we Włocławku przygotował i opublikował Pisma bł. biskupa Michała Kozala. Kazania, nauki rekolekcyjne i pasyjne, konferencje, przemówienia (Włocławek 2019). W roku sprawozdawczym wydano także 21 tom „Studiów Włocławskich”.

Oddział w Pelplini e. Oddziałem liczącym obecnie 36 członków kieruje ks. prof. dr. hab. Janusz Szulist. W roku sprawozdawczym doroczne spotkanie statutowe odbyło się 19 października w Bibliotece Diecezjalnej w Pelplinie. Ponadto Pelpliński Oddział Polskiego Towarzystwa Teologicznego współorganizował wraz z Kurią Diecezjalną, Zrzeszeniem Kaszubsko-Pomorskim oraz Wydziałem Teologicznym Uniwersytetu Mikołaja Kopernika V Areopag Pelpliński nt. 30 lat po transformacji ustrojowej w Polsce. Miłość małych i wielkich ojczyzn. Ta ogólnopolska konferencja odbyła się 19 października. W trakcie spotkania kierownik oddziału wygłosił wykład Początek transformacji ustrojowej $w$ Polsce na łamach polskiego wydania „L'Osservatore Romano”.

Oddział w Elblągu. Oddział w Elblągu jest najmłodszym z oddziałów. Prowadzi go ks. dr hab. Marek Karczewski, prof. Uniwersytetu Warmińsko-Mazurskiego w Olsztynie. Na dorocznym spotkaniu w dniu 9 grudnia z udziałem bpa dra Jacka Jezierskiego uczestnicy wysłuchali wykładu ks. dra Marka Piedziewicza nt. Metody apostolatu telewizyjnego abp. Fultona Sheena i wybrali nowy zarząd oddziału na trzyletnią kadencję.

\section{Sekcja Wydawnicza}

Kierownikiem Sekcji Wydawniczej jest Sebastian Wojnowski. W roku 2019 Sekcja Wydawnicza nie tylko prowadziła Wydawnictwo UNUM, co jest jej podstawowym zadaniem statutowym, kontynuowała też re- 
alizację projektów finansowanych przez Ministra Nauki i Szkolnictwa Wyższego, których celem było uzyskanie najwyższych standardów współczesnego publikowania naukowego.

Ukończone zostało repozytorium instytucjonalne - narzędzie formalnego publikowania wersji online w otwartym dostępie monografii naukowych ukazujących się w Wydawnictwie UNUM. Drugim celem repozytorium jest upowszechnianie archiwalnych publikacji wydanych przez Polskie Towarzystwo Teologiczne.

Kwartalnik „Ruch Biblijny i Liturgiczny” został przeniesiony do nowej wersji systemu wydawniczego i był publikowany w polskiej i angielskiej wersji językowej. W roku 2019 opublikowano w nim 16 artykułów naukowych, a także sprawozdania i recenzje.

Wydawnictwo UNUM opublikowało również wynik projektu pt. Kazania w kulturze polskiej. Edycje kolekcji tematycznych. Wynik projektu został opublikowany w dwóch wersjach - drukowanej i online w formie czterech recenzowanych monografii naukowych o łącznej objętości 160 arkuszy wydawniczych (2 400 stron) w serii Kazania w Kulturze Polskiej. Edycje Kolekcji Tematycznych nr 4-7:

- Kazania wielkanocne, wyd. i oprac. J. S. Gruchała, K. Panuś, Kraków 2019 (Kazania w Kulturze Polskiej. Edycje Kolekcji Tematycznych, 4), https://doi.org/10.21906/9788376431833.

- Kazania adwentowe, wyd. i oprac. W. Ostafiński, K. Panuś, Kraków 2019 (Kazania w Kulturze Polskiej. Edycje Kolekcji Tematycznych, 5), https://doi.org/10.21906/9788376431697.

- Kazania bożonarodzeniowe, wyd. i oprac. A. Jungiewicz, K. Panuś, Kraków 2019 (Kazania w Kulturze Polskiej. Edycje Kolekcji Tematycznych, 6), https://doi.org/10.21906/9788376431796.

- Kazania patriotyczne, wyd. i oprac. K. Panuś, M. Skwara, Kraków 2019 (Kazania w Kulturze Polskiej. Edycje Kolekcji Tematycznych, 7), https://doi.org/10.21906/9788376431819.

Wersja online została opublikowana w trybie otwartego dostępu gratis w Repozytorium Instytucjonalnym Polskiego Towarzystwa Teologicznego wraz z identyfikatorami obiektów cyfrowych DOI. Elektroniczna wersja publikacji została też bezpłatnie przekazana do repozytorium (biblioteki cyfrowej) jednostki zatrudniającej kierownika projektu Uniwersytetu 
Papieskiego Jana Pawła II w Krakowie, a także do repozytoriów jednostek zatrudniających pozostałych wykonawców.

Sekcja Wydawnicza prowadzi łącznie trzy serwisy internetowe:

- stronę wydawnictwa https://unum.ptt.net.pl, przez którą prowadzona jest sprzedaż wszystkich tytułów dostępnych w wersji drukowanej (na koniec roku 2019 było to ponad 200 tytułów),

- repozytorium instytucjonalne https://repozytorium.ptt.net.pl z wersjami online monografii naukowych (na koniec 2019 roku ponad 60 publikacji online)

- stronę kwartalnika https://rbl.ptt.net.pl zawierającą ponad 3,5 tysiąca tekstów dostępnych online.

17 grudnia 2019 roku Wydawnictwo UNUM zostało ujęte w wykazie wydawnictw publikujących recenzowane monografie naukowe Ministra Nauki i Szkolnictwa Wyższego (poziom I - 80 punktów).

\section{Uwagi końcowe}

Do najważniejszych dokonań zarządu Polskiego Towarzystwa Teologicznego w roku sprawozdawczym należy zaliczyć zatwierdzenie nowego statutu przez Konferencję Episkopatu Polski podczas 382 Zebrania Plenarnego w dniach 12-14 marca 2019 roku. Zarząd opracował program obchodów stulecia Polskiego Towarzystwa Teologicznego. Wydawnictwa UNUM Polskiego Towarzystwa Teologicznego zostało zamieszczone w wykazie wydawnictw publikujących recenzowane monografie naukowe prowadzonym przez Ministra Nauki i Szkolnictwa Wyższego.

Polskie Towarzystwo Teologiczne zrealizowało projekt Kazania w kulturze polskiej. Edycje kolekcji tematycznych finansowany Narodowego Programu Rozwoju Humanistyki, mający na celu opracowanie czterech antologii kazań: adwentowych, bożonarodzeniowych, wielkanocnych i patriotycznych. W staraniach o finansowanie projektów badawczych godne podkreślenia są wysiłki kierownika Sekcji Wydawniczej Sebastiana Wojnowskiego.

Na szczególne uznanie zasługuje ożywiona działalność oddziałów we Włocławku, w Sandomierzu i Szczecinie oraz krakowskich sekcji 
specjalistycznych: Biblijnej, Duchowości, Teologii Życia Konsekrowanego i Sztuki Sakralnej.

Polskie Towarzystwo Teologiczne posiada status kościelnej publicznej osoby prawnej i podlega nadzorowi Konferencji Episkopatu Polski. Stąd też zarząd na ręce ks. abp. prof. Marka Jędraszewskiego, arcybiskupa metropolity krakowskiego, oraz księży biskupów obecnych na walnym zebraniu składa serdeczne podziękowanie Konferencji Episkopatu Polski za troskę władz kościelnych o rozwój towarzystwa. Zarząd dziękuje również wszystkim aktywnym członkom towarzystwa, którzy mimo wielorakich trudności czynią wszystko, aby działalność towarzystwa była kontynuowana i służyła dalszemu uwrażliwieniu polskiego społeczeństwa na myśl teologiczną. 